\title{
A kognitív kérdoívtesztelés módszertana: a kognitív interjúk elemzése
}

Mújdricza ferenc,

a KSH fogalmazója

E-mail: Ferenc.Mujdricza@ksh.hu

\section{földvóri Móniko,}

a KSH főtanácsosa

E-mail: Monika.Foldvari@ksh.hu
Minden kognitív interjús kérdöívtesztnek kiemelten fontos része az interjúk elemzése, valamint annak eredményei alapján módosítások kidolgozása a kérdőiv fejlesztésére. A kognitív interjúk elemzésének speciális módszertana a közelmúltig nem csupán Magyarországon, de más országokban is elhanyagolt téma volt. Azóta viszont e hiány megszüntetésére számos tanulmány látott napvilágot a nemzetközi szakirodalomban; jelen írás szerzői e munkák alapján mutatják be a legfontosabb módszereket. A kérdezés-válaszadás folyamatának funkcionális teljességre törekvő elemzése egyszerre kell, hogy megfeleljen deskriptív (leíró) és reparatív (javító) igényeknek, amit jelenleg leginkább az interpretív iskola keretén belül kidolgozott, ún. grounded theory (megalapozott elmélet) alapú induktív interjúelemzés biztosíthat.

A szerzők különböző módszertani alternatívákat mutatnak be a kognitív interjúk elemzésére, melyek közül a témakódolásnak nevezett elemzési módszert fejtik ki bővebben, kitérve az induktív jelleg korlátaira és a teljes kognitív tesztfolyamat végcéljának tekinthető kérdőív-revíziós ajánlások kidolgozásának részleteire.

TÁRGYSZÓ:

Kérdőív.

Kognitív interjúfelvétel.

Módszertan.

DOI: $10.20311 /$ stat2018.06.hu0545 
A kognitív kérdőívtesztelés egy új keletủ, a CASM- (cognitive aspects of survey methodology - a kérdőívszerkesztés módszertanának kognitív aspektusai) mozgalom eredményeiből (például Jabine et al. [1984]) kialakult kérdőív-előtesztelési módszer. A kognitív interjús kérdőívteszt során a kérdések megválaszolásának lehetséges nehézségeit, valamint a válaszadók válaszaiba rejtett sajátos mentális tartalmakat és tapasztalatokat kívánjuk azonosítani. A módszer lehetőséget biztosít az összehasonlításokra is, így például a kérdőívfordítások pontosságának ellenőrzésére és a szociokulturális csoportok közötti ún. ekvivalenciavizsgálatra, vagyis a kérdőív-értelmezés és a válaszadás szociokulturális csoportjellemzők által meghatározott különbségeinek feltárására (Miller et al. [2014]). A tesztfolyamat kiemelt fontosságú eleme a kérdőív tesztelésére szolgáló interjúk elemzése, valamint annak eredményeként javaslatok kidolgozása a kérdőív módosítására és fejlesztésére. Ez a szükségképpen kvalitatív igényü elemzőmunka rávilágít a kognitív tesztfolyamat céljára: a tárgykérdőív revíziójára a kérdőívvel gyüjtendő adatok megbízhatóságának és érvényességének maximalizálása érdekében.

A kognitív interjút - mint arra Willis [2015] is felhívja a figyelmet - a gyakori fogalomkeveredések ellenére meg kell különböztetni a kognitív kérdőívtesztelés folyamatának egészétől, melynek az interjú a központi elemét képezi. Fogalmát Beatty és Willis ([2007] 288. old.; kiemelés az eredetiben) a következőképpen definiálják: „kérdőívvázlat kérdéseinek alkalmazása a kérdőív válaszairól további szóbeli információ gyüjtésével egyidejüleg, ami a válasz minőségének becslésére használható, illetve annak meghatározásában segít, hogy a kérdés a kérdőív szerzőjének szándéka szerinti információt generálja-e.”

A kognitív kérdőívtesztelés folyamata (a tervezéstől kezdve a mintaválasztáson és az interjúk lebonyolításán át az interjúk elemzéséig, a következtetések levonásáig és a tárgykérdőívre vonatkozó konkrét revíziós javaslatok megfogalmazásáig) a kognitív interjúk köré szerveződik. A kognitív interjús kutatások mindazonáltal nem csupán a kérdőív javítását szolgáló ún. reparatív megközelítés, hanem az ambiciózusabb deskriptív (Millernél [2011] integratív) szemlélet alapján is elemezhetik az interjúkat. Utóbbi célja az egyszerủ problémakeresés helyett annak általánosabb megértése, hogy a kérdések miként funkcionálnak egy bizonyos fogalom, jelenség mérőeszközeiként (Willis [2015]). Willisszel [2015] szemben azonban megjegyezhetjük, hogy a két megközelítés nem csupán egy módszertani kontinuum két végpontjaként értelmezhető. Egy funkcionális teljességre törekvő reparatív kognitív interjús kutatás ugyanis mindkét elemet, a deskriptív és a reparatív megközelítést integrálva érheti el a legjobb eredményt. Jelen tanulmányban a kérdések funkcionalitásának megértésére alapozó és diszfunkcióik feltárására, javítására szolgáló, integrált deskriptív-reparatív 
kognitív kérdőívtesztelés elemzési módszereinek leírására vállalkozunk a rendelkezésre álló nemzetközi szakirodalom alapján.

A kognitív kérdőívtesztelés során, ami nemreprezentatív, célzott, kvótás mintán történik, az egyedi esetek kvalitatív elemzésével azonosíthatók a tárgykérdőívre vonatkozó döntések meghozatalához szükséges információk és mintázatok. Ezért nem hagyományos statisztikai eszközök, hanem egyedi interjúkomplexumokban való módszeres elmélyedés révén juthatunk minőségi eredményekhez. A kvalitatív igényü kutató Miller [2011] szisztematikusságot, módszertani hitelességet és átláthatóságot szorgalmazó, illetve az önkényesség kizárását támogató megközelítését elismerve sem feledheti: a jó elemzés bizonyos mértékben mindig mủvészi is (Beatty-Willis [2007]).

A kognitív interjúk elemzésének módszertana kiemelt fontossága ellenére a közelmúltig kifejezetten elhanyagolt téma volt (Collins [2015b]), pedig elengedhetetlen, hogy a kutatók megfelelő, szisztematikus, hiteles és átlátható (Miller [2011], Miller et al. [2014]) módszertant alkalmazzanak. A Beatty és Willis [2007] által említett művészi érzékenység és a stabil módszertani keretek párosítása biztosíthatja a kognitív tesztfolyamat sikerességét és minőségi eredményét. A továbbiakban a nemzetközi szakirodalomra támaszkodva igyekszünk az olvasó elé tárni a kognitív interjúelemzés legfontosabb módszereit.

\section{A kognitív interjúelemzés elméleti alapjai}

A nemzetközi szakirodalom alapján a kognitív interjúelemzés gyakorlatába Miller [2011], Willson és Miller [2014], illetve Miller et al. [2014] által bevezetett ún. grounded theory (megalapozott elmélet) (Glaser-Strauss [1967], Charmaz [2006]) módszertani keretei adnak leginkább megfelelő és teljes eszközkészletet a kognitív interjúelemzés kihívásaira. A grounded theory hiteles áttekintését nyújtja magyar nyelven Mitev [2012] összefoglaló tanulmánya. Mitev szavaival élve Glaser és Strauss [1967] módszere „a »kvalitatív forradalom« zászlóvivője” (Mitev [2012] 17. old.). Kidolgozói szerint a grounded theory - a deduktív kutatási logika egyeduralmával szemben fellépve - induktív módon, előzetes elméleti elköteleződés nélkül (de az elméleti háttér tanulmányozását nem elvetve), empirikus adatokra közvetlenül visszavezethető és átlátható elméletalkotást tesz lehetővé. Az adatgyüjtés és -elemzés „organikus" formában, részben egymásba fonódva zajlik. A kutató az adatok elemzésével és kódolásával jut el az adatok megértéséhez és az elméleti belátásokhoz. Majd az elemzési folyamat végén ezeknek az értelmezéseknek az összes adattal való folyamatos összehasonlítása és kiigazítása után hoz (elvben minden tekintetben) az adatok tartalmát reprezentáló, az adatokból „kiemelkedő” és azokra visszavezethető következteté- 
seket. A grounded theory különösen alkalmas eszköz a jelentésalkotási folyamatok és a valóság egyedi vagy társas interpretációinak feltárására, megértésére (Mitev [2012]). E tény magyarázhatja, hogy újabban miért fordulnak a kognitív kérdőívtesztelés képviselöi egyre inkább e módszer felé. A grounded theoryra épülő kognitív interjús kutatásmódszertan legalaposabban kidolgozott elméleti bázisa pedig a Miller [2011] által felvázolt, majd Chepp és Gray [2014] által továbbfejlesztett interpretivista megközelítés, amit Willis ([2015] 33. old.) is „különleges figyelmet érdemlőnek” titulál.

Az interpretivista iskola, ami a kognitív interjúzás korai szakaszában egyeduralkodó volt, de még ma is meghatározó, a kérdezés-válaszadás folyamatának kognitív pszichológiai modelljét (Tourangeau [1984]) szociológiai szempontok alapján kiegészítve a folyamat társadalmi meghatározottságára hívja fel a figyelmet. Tourangeau és követői egy kérdőívkérdés feltételezett általános jelentésmagjának megértési-reagálási folyamatára fókuszálnak (Willis [2015]). Az interpretivisták e modellt a kognitív szociológia szemszögéből kibővítve kihangsúlyozzák: egy kérdőív válaszadóinak a kutató szándékától gyakran kisebb-nagyobb mértékben eltérő, társadalmi helyzetük által is meghatározott értelmezései a kérdések és válaszlehetőségek révén mérni kívánt jelenségek tekintetében idővel, a válaszadók körülményeinek, tapasztalatainak változásával módosulhatnak. A kognitív interjúk elemzése e sokrétü, állandó változáspotenciált hordozó jelentésmintázatok azonosítását és értelmezését teszi szükségessé a tesztalanyok ${ }^{1}$ gondolkodását és megértését szervező kategóriák, sémák és kódok feltárása útján (Chepp-Gray [2014]). Ezek az egyéni jelentésmintázatok, kategóriák, sémák és kódok a kérdésekre való válaszadás folyamatában nyilvánulnak meg. Chepp és Gray 2014-ben megjelent tanulmányukban Tourangeau [1984] gyakran idézett négy kognitív stádiuma (felfogás, felidézés, döntés és válaszadás) mellett Brekhus [2007] modelljét tekintik mérvadónak e folyamat megértésében. Az utóbbi ugyanis a tudati folyamatokat a társadalmi környezet hatásaira is érzékenyen, tág megközelítésben mutatja be, hat kognitív folyamatot kiemelve: 1 . észlelés, 2 . figyelem/figyelmetlenség, 3. emlékezet/idő/kronológia, 4. besorolás, 5. jelentéstulajdonítás és 6 . szociális identitás. A kérdezés-válaszadás folyamata vonatkozásában a két megközelítésmód Chepp és Gray [2014] szerint is hasonlatos egymáshoz. Így, noha a kognitív interjús szakirodalomban ma is a Tourangeau-féle felosztás a meghatározó forrás (Willis [2015]), az újabb keletü interpretivista szempontok megjelenésével az kiegészül a tudati folyamatok társadalmi környezet által is formált jellegének tézisével.

Willis [2015] szerint a kognitív interjúzás az adatgyüjtést és -elemzést egy folyamatban egyesítő bayesiánus megközelítéssel rokon. A grounded theory induktív

\footnotetext{
${ }^{1}$ A félreértéseket elkerülendő meg kell jegyeznünk, hogy Willis [1994] a „válaszadó” kifejezést a terepmunka lekérdezettjére vonatkoztatva javasolja alkalmazni, megkülönböztetve a „laboratóriumi” kérdöívtesztelés alanyától. Az esetleges félreértések elkerülése érdekében a jelen tanulmányban mi is szükségesnek tartjuk alkalmazni e megkülönböztetést. Ezért a „,válaszadó” kifejezés a jelen tanulmány kontextusában arra a személyre utal, akivel a kérdőívtesztelés tárgyául szolgáló kérdőív végül majd lekérdezésre kerül, a kérdőívtesztelés alanyára pedig - kontextustól függően - az „interjúalany” vagy „tesztalany” szavakat használjuk.
} 
módszertani kereteinek kognitív tesztekben való alkalmazásából következően ugyanis ideális esetben a célunk az ún. elméleti telítettség elérése. Elméleti telítettségről akkor beszélhetünk, amikor az interjúk elemzése során azonosított problémák, értelmezések mindegyike magyarázható a többi interjú kontextusában is (Charmaz [2006], Willson-Miller [2014]). Ez csupán a mintavétel, az adatgyüjtés, valamint az elemzés párhuzamos, dinamikus, szervesen összefüggő folyamatában valósítható meg. A három folyamat így optimális esetben egymásba fonódva zajlik, és nem választható szét a deduktív kutatási logikát követő társadalomtudományi kutatásoknál megszokott módon, ahol a mintavétel és az adatgyüjtés időben megelőzi a kutatás kései szakaszában zajló elemzőmunkát (Miller [2011]). Megjegyzendő azonban, hogy az elméleti telítettség eléréséhez szükséges mintavételi, adatgyüjtési és elemzési munka a gyakorlatban igen ritkán valósítható meg kompromisszummentesen, hiszen az hosszú hónapokig vagy akár évekig terjedő, előre meghatározhatatlan idő- és erőforrás-igényű folyamat is lehet (Willis [2015]). A statisztikai adat-előállítás valós keretei között legjobb esetben is néhány iteratív mintavételi-adatgyüjtési kör és az ismétlések közötti elemző szakaszok formájában nyílik lehetőség az elméleti telítettség elérését célzó, dinamikus-organikus optimum szimulált megközelítésére. A következőkben bemutatásra kerülő elemzési módszertan tehát ennek fényében alkalmazandó - a rendelkezésre álló erőforrások függvényében - egy párhuzamos vagy iteratív mintavételi-adatgyüjtési-elemzési munka részeként, az elemzés eredményeit folyamatosan beépítve a teljes folyamatba.

\section{Elemzési módszertan}

Willis [2015] egy egész könyvet szentel a kognitív interjúelemzés korábban elhanyagolt témájának; a kötetben tárgyalt összes szempont és módszer kimerítő tárgyalása azonban nyilvánvalóan meghaladja a jelen tanulmány kereteit. A legfontosabbnak ítélhető megállapításainak és a kérdés további mérvadó szakirodalmainak (Miller et al. [2014], D’Ardenne-Collins [2015], Collins [2015b]) összegzésével viszont már felvázolható egy gyakorlatban is alkalmazható elemzési keretrendszer.

Willis [2015] öt elemzési modellt mutat be, mindegyiküket rendkívül alaposan tárgyalva az általuk használt módszerek szerint. A modellek két fő kategóriára oszthatók:

1. az interjúkból származó adatokat kódolatlan formában elemző megközelités, melyhez csupán a szöveges összefoglalók modellje tartozik; illetve 
2. az adatokat kódolt formában elemzö megközelitések; az ezekhez sorolható négy modell két alkategóriába rendezhető:

a) fentről-lefelé építkező (vagy deduktív) kódoláson alapuló modellek: előzetesen meglevő elméleti (például kognitív pszichológiai) keretekhez igazodó kutatói irányultság alapján megalkotott, esetleg valamilyen más kvalitatív kutatásmódszertanból átemelt a priori kódok alkalmazása az adatokra. Ebben az esetben tehát elöre kialakított vagy már meglevő kódokat rendelünk az interjúk nyers adataihoz;

b) alulról-felfelé építkező (vagy induktív) kódoláson alapuló modellek, melyek kidolgozói visszautasítják bármilyen előzetesen kialakított kódrendszer használatát. Helyette a nyers adatok intenzív elemzése útján egyedi kódrendszer felépítését, majd annak az interjúk adataira való alkalmazását javasolják.

Kódok két szinten alkalmazhatók. Egyrészt az interjúk szintjén az egyes kérdésekre (ez a leggyakoribb megoldás), másrészt az interjúnkénti szöveges összefoglalókból képezhető kérdéscsoportok szintjén. Az előbbi esetben az összes interjú minden egyes kérdésével kapcsolatosan, míg az utóbbiban csak az egyes kérdéscsoportokról hozunk döntést a kódolás tekintetében.

A következőkben Willis [2015] összefoglalója alapján mutatjuk be az elemzési modellek legfontosabb jellemzőit.

\subsection{Szöveges összefoglalók}

A szöveges összefoglalókra épülő, etnográfiai jellegü elemzés egyszerüségének köszönhetően uralkodónak számít a kognitív tesztelésben. E modell, habár lényegében a kérdezői jegyzetek összesítésével kiemelkedő domináns motívumokra, illetve az azokból levonható következtetésekre és feltárható problémákra épül (ami nem zárja ki a szisztematikus és lelkiismeretes elemzőmunkát), nagy teret enged a módszertani szempontból kényesnek tekinthető önkényes értelmezéseknek, a felületes kutatói megközelítésnek. Utóbbira hajlamosíthat az a tévképzet, hogy a szöveges összefoglalók készítése egyszerübb, illetve könnyebb volna, mint az alternatív lehetőségek megvalósítása. A felületesség veszélyére utalnak a róla alkotott, gyakran elítélő vélemények is, melyek azt puszta jegyzetösszegzésnek, a kérdőívkérdésekre adott válaszok egyszerủ összefoglalójának tekintik.

A szöveges összefoglaló egy-egy vizsgált kérdés tekintetében lehet fogalmazványszerủen kifejtett, de csupán a legfontosabb elemekre összpontosító, jegyzetszerủ is. Jellemzően reparatív orientációjú kutatásokban alkalmazzák, így az elemzés 
eredményéül szolgáló összefoglalók a problémák azonosítását és azok javasolt megoldásait tartalmazzák. Noha az egyes kérdésekben rejlő eredeti kutatói szándék is megjelenik az összefoglalókban, gyakori hiányosságuk, hogy alkalmazóik elsősorban a problémák meghatározására fókuszálnak, figyelmen kívül hagyva a kutatói és a válaszadói értelmezés átfedését. A cél ugyanakkor ennek az átfedésnek a maximalizálása lenne. A kutatói-válaszadói értelmezés azonossága mögött meghúzódó motívumok, mintázatok ismeretében ugyanis nyilvánvalóan megnő annak az esélye, hogy módosítandó kérdéseinkre megfelelő alternatívákat tudjunk alkotni, továbbá olyan szempontokra, ismeretekre, tapasztalatokra is szert tehetünk, amelyek a későbbi hasonló vagy akár azonos csoportokat célzó más kutatások kérdőíveinek tervezési szakaszában is hasznosíthatók. Összességében tehát a reparatív igényü kognitív interjúzás sem engedheti meg magának a deskriptív szempont figyelmen kívül hagyását, ugyanis nélküle a kérdőív-revíziós javaslatok nem lennének kellően megalapozottak. Az elemzésre fordított többletenergia nem csupán megtérül, de kifejezetten kifizetődőbbnek is tủnik, mert pontosabb, a mérőeszközből fakadó hibát egy tesztelési hullámban is a lehetőségekhez mérten leginkább minimalizáló analízist tesz lehetővé.

Egy igényesen elkészített szöveges összefoglaló mindazonáltal lehetőséget nyújt a következő problémák megragadására, a kérdezés-válaszadás Tourangeau-féle [1984] klasszikus kognitív folyamatában is:

- inputhibák (eltérés van a kutató és az interjúalany kérdésértelmezése, felfogása között);

- feldolgozási hibák (az interjúalany képtelen előhívni a szükséges adatokat/információkat a memóriájából); valamint

- outputhibák (az interjúalany nem képes vagy nem hajlandó megalkotni a megfelelő választ).

A válaszadói csoportok szociokulturális jellegzetességeinek figyelembevételével pedig a túlzottan mechanisztikus kognitív pszichológiai kérdezés-válaszadási modell hátrányai is kiküszöbölhetők (Willis [2015]).

Az elöbbiekben leírtakon túl a szöveges összefoglalók modelljének további elönyei:

- Idö- és eröforrás-hatékonyság: kódolás hiányában viszonylag gyorsan elvégezhetö.

- Nagy adatgazdagság: a szövegre összpontosítva és a kódolásos adatredukciót nélkülözve olyan részletes információkat nyújt, amelyek a problémák diagnosztizálásában és megoldásukban is előnyösek lehetnek. 
Hátrányai:

- Nagy terjedelem: a hosszú összefoglalók feldolgozása nehézségeket okozhat.

- Hiányos elemzés: az elemzendő anyag (kódolatlan szövegek: jegyzetek, idézetek stb.) terjedelméből fakadóan általában csupán a problémákra fókuszáló elemzések születnek, és nem kerül sor azoknál elönyösebb, kérdésfunkciókat is feltáró analízisre.

- Megalapozott keretek hiánya: kódrendszer használata nélkül a formailag különböző, de tartalmilag azonos (vagyis azonosan kódolandó) megfogalmazások közötti konzisztenciák feltárása esetleges, kétséges és nehezen ellenőrizhető.

Következésképpen a kizárólag szöveges összefoglalókon alapuló elemzés csak különösen indokolt esetben felelhet meg a minőségi kognitív interjúelemzés kívánalmainak, így használata minden esetben indoklást igényel.

\subsection{Kognitív kódolás (kognitív szemléleten alapuló, fentről-lefelé történő kódolás)}

Ez a kognitív kódolásra épülő elemzési modell csupán annyiban különbözik az előzőtől, hogy a szöveges összefoglalók formalizálásaképpen a kérdezés-válaszadás Tourangeau-féle [1984] kognitív pszichológiai folyamatmodelljéből elöállított problémaazonosító kódokat rendeli a tesztalanyok válaszaihoz a szöveges kiértékelés során. Habár ez esetben a kognitív modell kiegészül egy további, „logikai problémáknak" nevezett kategóriával (és az ahhoz tartozó kóddal), a kognitív kódolás elméleti hátteréből következően alkalmatlan a jelentések megragadására, és ezáltal részletes, a deskriptív és a reparatív igényeket egyaránt kielégítő elemzésre.

E modell használata jellemzően a szöveges adatok egyszerü kódkészlettel történő redukcióját jelenti, azonban bizonyos (ritka) esetekben az egyes kérdésekre vonatkozó szöveges összefoglalók készítése is elmarad. Idetartozik például a számítógépes célprogram segítségével automatizált kulcsszavas „elemzés”, ami azonban, mint Willis ([2015] 76. old.) fogalmaz, „még az emberi elme feldolgozóképességének elemi szintjét sem” éri el, és így a valós problémákat csak „rendkívül korlátozottan” képes feltárni.

A modell elönyei:

- Összehasonlithatóság: e modell módszere alapján végzett kutatások az azonos kódkategóriákból fakadóan összehasonlíthatók egymással. 
- Elméleti megalapozottság: a kognitív interjúzással szemben gyakran felhozott, elméleti megalapozottságot hiányoló kritika a - jóllehet kezdetleges - Tourangeau-féle kategóriákhoz kötött elemzés esetében nem állja meg a helyét.

A modell hátrányai:

- Számszerüsités: Willis ezt a jellegzetességet a módszer előnyei közé sorolja, véleményünk szerint azonban helytelenül. A jellemzően tervezett, nemreprezentatív, nemvalószínűségi, kvótás mintán alapuló (például Willis [2005], Beatty-Willis [2007], Willson-Miller [2014], Collins-Gray [2015] stb.) kognitív tesztek esetében a célközönség felé „csalóka képet” közvetít egy százalékos eloszlásokat közlö munka. A vizsgált populációra ugyanis ezek az eloszlások a mintavétel jellege okán nem általánosíthatók. A kognitív teszt során minden egyes eset azonos súllyal esik latba akár gyakoribb, akár ritkább egy adott jelenség (probléma, értelmezésmód stb.) feltünése a mintában.

- Uniformizáló megközelítés: Előre meghatározott, uniformizált kognitív kódok alkalmazása bármilyen adatra az előzőkben leírtak alapján (a szociokulturális tényezőket ignorálva) túlzott leegyszerüsítést eredményez szemben az alulról építkező megközelítésekkel, melyek az adatokból „kiemelkedő” kódrendszerrel nagyobb validitást érnek el.

- Kódolásból fakadó információveszteség: a kezdetleges kognitív kódolással járó adatredukció elkerülhetetlenül radikális információvesztést eredményez.

- Korlátozott kódkészlet: a kognitív kódséma minden, a kognitív modellben foglalttól különböző faktort kizár az elemzésből.

Összességében tehát a kognitív kódolás a ma már túlhaladottnak tekinthető elméleti alapjai és súlyos korlátozottságai miatt az alapszintü elemzési igények kielégítését sem biztosítja, így alkalmazása nem javasolt.

(Megjegyzendő, hogy a Collins által szerkesztett, több tekintetben kifejezetten hasznos és korszerü útmutatónak tekinthetö könyvben [2015a] az elemzés témájának szentelt fejezet (Collins [2015b]) lényegében a kognitív kódolás módszerének egy „kései”, részletesen és igényesen kidolgozott, alapos útmutatója. Noha a szerző az adatokban induktív módon keres mintázatokat, az azonosított mintázatokra már a Tourangeau-féle [1984] négyelemü kognitív modell kódjait alkalmazza. A kognitív kódolás elemzési modelljének e módosított változata, amit bár vegyes módszernek is tekinthetnénk, az eredményekre kritikus hatást gyakorló kódkészlet elméleti hátteré- 
nek viszonylag elavult volta miatt nem javasolható az általános elemzési gyakorlat eszközéül, mivel az előbb részletezett korlátokba ütközik.)

\subsection{Kérdésjellegzetességek kódolása}

A tesztalanyok mentális folyamataira koncentráló kognitív kódolással szemben e modell a mérőeszköz (a kérdőív és a kérdések) jellegzetességeinek válaszadást befolyásoló hatásain alapul. Olyan kategóriarendszert hív segítségül, amely problémás vagy más szempontból fontos kérdés-/kérdőívjellemzőkön alapul, így a fókusz a tesztalany kognitív folyamatairól az azokból fakadó hibákra tevődik át. Gyakran előforduló, mérőeszközből származó probléma például az, amikor a kérdés megfogalmazása egy helytelen feltételezés miatt nem „illeszkedik” a válaszadó helyzetéhez. Ilyen például egy, az elmúlt 12 hónapban igénybe vett egészségügyi szolgáltatások részleteire vonatkozó kérdés (releváns válaszlehetőség nélkül) olyan válaszadó esetén, aki nem részesült a referenciaidőben egészségügyi kezelésben, vagy nem vett részt egészségügyi vizsgálaton.

A kérdésjellegzetességek kódolásán alapuló keretrendszer több módszerben is megjelenik. Ezek közül Willis [2015] a saját, Lesslerrel közösen (Willis-Lessler [1999]) kidolgozott QAS- (question appraisal system - kérdésértékelő rendszer) modelljüket emeli ki, melynek bővebb bemutatása önmagában is önálló tanulmányt igényelne. Mindazonáltal, mint az az eredeti dokumentum bevezetésében is olvasható, a módszer elsősorban a kérdésalkotásnak a kérdések „bevetése” előtti fázisában használandó mint minőségi kérdőívszerkesztési útmutató és önteszt (Willis-Lessler [1999]) vagy mint a kérdőív szakértői véleményezéséhez (ami maga is egy különálló kérdőív-előtesztelési módszer) használatos ellenőrzőlista (Willis [2015]). Alkalmazása fenntartás nélkül javasolható, de optimális esetben nem elsősorban a kognitív kérdőívtesztelési, hanem az azt megelőző kérdőívszerkesztési fázisban. Kérdéses minőségủ kérdőívszerkesztési fázis esetén azonban egyfajta előzetes ellenőrzésként a kognitív tesztfolyamat elejére is beilleszthető, a feltárt problémák pedig így még az interjúzás előtt javíthatók lesznek. Ezen túlmenően a kognitív teszt eredményeképpen felülvizsgált kérdésekre is érdemes a QAS ellenőrzőlistáját alkalmazni, hogy szakmailag megfelelö javaslatokat fogalmazhassunk meg.

A QAS-modellen alapuló kódrendszer mellett léteznek hibrid kódsémák is (Willis [2015]). A hibridjelleg a kognitív modellre és a kérdésjellegzetességekre épülő kódrendszer valamilyen kombinációjából adódik, minthogy mindkettőnek sajátja a fentről-lefelé irányuló kódolási logika. Ezek bővebb tárgyalása itt nem indokolt, tekintve, hogy az interjúelemzés kódolási eszközeként kevésbé javasolható Tourangeauféle kognitív modell megközelítését vegyítik az elsősorban kérdöív-ellenőrzésre kifejlesztett eszközzel. 
Egy további hibrid modellt alkotnak a fentről-lefelé építkező kódolási megközelítésbe szociokulturális és nyelvi elemeket beemelő módszerek. Ezek kódolási sémája azonban Willis [2015] szerint jellemzően túlzottan általános és továbbfejlesztést igényel. A leghasználhatóbb közülük Lee [2014] nemzetközi kutatásokra alkalmazott megoldása, aki a QAS-t egészítette ki kulturális vonatkozású kódelemekkel.

A kérdésjellegzetességek kódolásán vagy annak bármilyen hibrid változatán alapuló módszerek előnyei és hátrányai lényegében megegyeznek a kognitív kódolásra épülő modell előnyeivel és hátrányaival, így itt nem szükséges azokat újra kifejtenünk. Mindent összevetve kijelenthető, hogy e módszerek alkalmazása, számításba véve forrásuknak, a QAS kérdőív-értékelő rendszernek az eredetileg nem interjúelemzésre alkotott jellegét is, még hibrid, más megközelítésekkel kombinált formában sem javasolt az elemzés során. Ezzel szemben a QAS vagy annak Lee-féle bővített verziója kifejezetten ajánlható a tesztelendő kérdőív előzetes, illetve a revizionált kérdésváltozatok „,biztonsági” ellenőrzésére.

A következő két modell a lentröl-felfelé irányuló kódolási logikára épül. Ennek következtében az elemzés korai szakaszaiban annyiban hasonlítanak a szöveges öszszefoglalók módszeréhez, hogy az interjúkat „bányászva” keresik azokat a jelentésteli információkat, melyek a kódrendszer (témák vagy mintázatok) alapjául szolgálnak. A kódok a fontosnak ítélt felismeréseket reprezentálják, és lehetővé teszik a komplex összefüggések átlátható és szisztematikus feltárását.

\subsection{Mintázatkódolás}

E megközelítés, hasonlóan a többi modellhez, az adatokban keres mintázatokat, de ellentétben velük, az interjúkból „kiolvasott” tényezők közötti viszonyok feltárására irányul (Willis [2015]). Nem csupán az adott kérdés, de más kérdőívrészek, a tesztalany jellemzői és a szociokulturális háttér is ilyen tényező lehet, melyek összefüggései alapján „látunk bele” egy kérdés és a kérdőív egészének müködésébe. ${ }^{2}$ Willis szerint a mintázatkódolás lehetővé teszi az egyszerre deskriptív és reparatív igényü elemzést, azaz nem csupán a problémákra koncentrál. Mi azonban eltérő véleményre jutottunk a modellt leíró, Willis által használt forrás (Miller et al. [2010]) megismerése után.

Willis [2015] elsősorban Miller et al. [2010] összesen 15 közép- és dél-amerikai, ázsiai és afrikai országon átívelö, nagymintás $(N=1290)$, kultúraközi kognitív interjús kutatása alapján mutatja be a modell jellegzetességeit. A példának választott kutatásban (ami a maga nemében egyedülálló) a kvalitatív vizsgálatokra és a kognitív kérdőívtesztekre jellemző kis elemszámú mintákhoz képest rendkívül nagy mintaelemszám miatt alakították ki a közvetlen mintázatkódolás módszerét. Ebből

\footnotetext{
${ }^{2}$ A kérdések „müködésének” megértése valójában annak vizsgálata, hogy a válaszadók miként értelmezik és válaszolják meg azokat (Földvári-Mújdricza [2018]).
} 
következően az elemzés elsősorban kvantitatív jelleget ölt. A konzisztens vagy inkonzisztens válaszmintázatok a tesztelendő kérdőív kérdéseire, valamint a kérdésekhez kapcsolt ellenőrző interjúkérdésekre adott válaszokból állnak össze.

A mintázatkódolás az ún. adatmegjelenítésen alapszik, vagyis valamilyen mátrix, grafikon, hálózat vagy diagram útján igyekszik könnyen hozzáférhetö, kompakt módon ábrázolhatóvá tenni az adatokat, így könnyítve meg az összefüggések és a tendenciák felismerését. A módszer tehát az eredmények számszerüsítésére és az inkonzisztens mintázatok feltárására épül. Miller et al. [2010] tanulmánya azonban nem közöl semmilyen támpontot az interjúk kvalitatív igényü kérdéseire adott válaszok elemzésével kapcsolatosan, csupán annak eredményét közli azokban az esetekben, amikor a kvantitatív mintázatelemzés problémákat tárt fel.

Noha a tanulmányban ismertetett kutatás valós eredményekre jut a mintázatkódolással, a kognitív kérdőívtesztelés általános elemzési módszeréül nem javasolható. Minthogy a kognitív tesztek a gyakorlatban jellemzően kis, $N=5-50$ fös mintán zajlanak, az inkonzisztens mintázatok demográfiai jellemzőkkel való, statisztikailag szignifikáns összefüggéseinek kimutatására az extrém különbségeken túl igencsak kis esélyünk van. A modellre tehát elsősorban a nagymintás kognitív interjúk makroszintủ elemzési keretrendszereként tekinthetünk. A kognitív interjúelemzés kvantitatív jellegü módszereként csak extrém nagymintás teszt esetén javasolható, megfelelő, kvalitatív adatok elemzésére szolgáló módszertannal kiegészítve.

A mintázatkódolás előnyei (Willis [2015]):

- Mélységében összpontosit a kérdésfunkciókra: általánosságban valóban igaz ez a megállapítás, hiszen a kérdőív kérdéseire, az ellenőrzőkérdésekre és más kérdőívkérdésekre adott válaszok szisztematikus mintázatokba rendezésével gazdag, részletesen elemezhető struktúrához jutunk.

- Deskriptív és reparativ célokra egyaránt alkalmas: a konzisztens és inkonzisztens mintázatok bemutatása révén a deskriptív igénynek is megfelel, ám - az előbb kifejtett véleményünk szerint - csupán részlegesen. A mélyebb szintü elemzés csak a problémás esetekben (inkonzisztens válaszoknál) valósul meg, ami mindenesetre teljesíti a reparatív igényt.

- Strukturálja a kognitív interjút: a táblázatok, diagramok stb. segítségével történő adatmegjelenítésre épülő elemzés az interjúzás során specifikus információk begyüjtését követeli meg. Willis [2015] ezért a táblázatok fejlécének előzetes elkészitését javasolja, ami az interjú során útmutatóul szolgálhat.

- Alkalmas nagymintás vizsgálatokhoz: több kutató(hely) együttmüködésében százas vagy akár ezres nagyságrendủ interjúk lebonyolí- 
tására és elemzésére is megfelel az interjú elemzési módszervezérelt (ti. adatmegjelenítésre épülő) előzetes strukturáltsága. Az elemző kifáradásának veszélye csökkenthető általa.

- Energia- és időigénye relative alacsony: bármilyen más módszer kielégítóen igényes alkalmazása hasonlóan nagy vagy még nagyobb terhet róna az elemzőre azonos mintaméret esetén. E módszer hasznossága éppen abból fakad, hogy más opciókhoz képest relatív alacsony terhelést jelent, miközben nagy minta esetén is átlátható és ésszerü keretek között, standard módon kivitelezhető.

A modell hátrányai (Willis [2015]):

- Felhasználási köre erösen korlátozott: eredetileg nagyszámú, több országban felvett interjúkhoz kidolgozott protokollként a modell igazi potenciálja csak nagymintás vizsgálatokban aknázható ki. Az előzőkben leírtakkal összhangban ezért alkalmazhatósága kétséges a kognitív interjúzásban gyakori kismintás kutatásokban.

- A kvalitatív interjúelemek elemzéséhez nem nyújt támpontot.

- Az interjút túlstrukturálttá teszi: az elemzésben használandó táblázatok, diagramok által előzetesen strukturált forma meggátolhatja az interjúszituációkra rugalmasan reagáló, kreatív kérdezést, így az adatokban a váratlan helyzetek következményei nem képeződnek le. A rugalmatlan (vagyis a táblázatok kitöltéséhez minimálisan szükséges kérdésekre szorítkozó) interjúzás tehát kerülendő, az elemzés során pedig biztosítani kell az adatgyüjtés utáni táblázatmódosítás lehetőségét. Így a nem várt eredmények is feltüntethetők lesznek. A rugalmas kérdezői és elemzői magatartás negatívan hathat az interjú strukturáltságából eredő összehasonlíthatóságra is.

- ,Gyanúsan fentröl-lefelé” irányul: Willis megjegyzését ([2015] 107. old.) a módszer fentről-lefelé építkező kódolásra is alkalmas jellegéről kiegészíthetjük azzal, hogy amennyiben az interjútervezést és -elemzést elsősorban az adatmegjelenítésre szolgáló, előre megtervezett táblázatok cellakitöltése vezérelné, az adatok alapján azonosítható mintázatok egy korábban megszerkesztett kódmátrix szerint rendeződnének. Ez pedig a fentröl-lefelé irányuló kódolás logikájának felel meg, amelynek hátrányait már ismertettük. Amennyiben az interjúzás és az elemzés során rugalmas, reaktív kérdezői-elemzői akciókra is lehetőség van, úgy egyfajta „vegyes”, egyszerre fentről-lefelé és alulról-felfelé építkező kódrendszer jöhet létre. Ezért a mintázatkódolás modelljét talán helyesebb volna a két kódalkotási megközelítés közötti határra helyezni. 


\subsection{Témakódolás}

A legújabb kognitív interjúelemzési modell a Willis [2015] által - némiképp pontatlanul - témakódolásnak nevezett megközelítés. A félreértéseket elkerülendő előrebocsátjuk, hogy a Willistől származó elnevezésbeli pontatlanság ellenére a témakódolásra épülő elemzés folyamatának is része a mintázatok azonosítása, ami azonban más módon történik, mint a nagymintás tesztekre kidolgozott speciális mintázatkódolás esetén.

A témakódolás egy, a korábban bemutatott interpretivista szemlélethez kapcsolódó, grounded theory alapú elemzési modell, ami mára a legszélesebb körben használt kognitív interjúelemzési módszerré vált (Willis [2015]). Leginkább a Miller et al. [2014] által kifejtett módszer biztosíthatja a kognitív teszt elemzési fázisának átláthatóságát, vagyis a vizsgálatnak és eredményeinek a megbízhatóságát és hihetőségét. Egyfelől elkerülhető általa az egyes kiemelkedő esetek anekdotaszerú, megbízhatatlan összegzésekhez vezető túlhangsúlyozása a többi kárára (Miller et al. [2014]). Másfelöl kiküszöbölhető a kvantifikációs eszközöket használó elemzőmodellek megoszlási táblázatainak elemzőmunkát torzító veszélye is, mivel az ilyen táblázatok arra hajlamosíthatnak, hogy a ritkábban előforduló eseteket kisebb fontosságúakként kezeljük. Eredményeink a nemreprezentatív minta okán sosem általánosíthatók, mindig tényszerüek, vagyis arra mutatnak rá, hogy a leírt mintázat, feltárt probléma létezik. Nem tudhatjuk azonban, hogy egy bizonyos értelmezési mintázat vagy probléma a populáció mekkora részére jellemző, milyen arányban felelös az adatgyüjtési hibákért (Miller et al. [2014]). Ez azonban nem is célunk. Így a kognitív teszt során a megoszlások vizsgálatára építő minden elemzés eleve rossz megközelítésü, hiszen fogalmunk sincs, hogy a populációs eloszlások milyen eséllyel követik a mintabelieket. Minden egyes esetet (értelmezést, problémát, mintázatot stb.) azonos súlyúként kell kezelnünk az elemzés és az eredmények bemutatása, majd a következtetések levonása és az azokra épülő módosítási javaslatok kidolgozása során, akár gyakran, akár csupán egyetlen alkalommal fordul is az elö.

Willis [2015] megállapításai alapján és azokat kiegészítve a témakódolásra épülő analitikus modell következő előnyeit és hátrányait azonosíthatjuk.

Elönyök:

- Illeszkedik az adatokhoz, mivel a kódokat (témákat) az interjúszövegekből alakítjuk ki.

- Leirja a teljes kérdésfunkciót: hozzájárul a kérdésekkel kapcsolatos megalapozottabb döntéshozatalhoz. Segítségével olyan kérdésfeltevési vagy -módosítási lehetőségek merülhetnek fel, melyek az egyszerü reparatív megközelítés esetén „homályban” maradnának. 
- Egyaránt kielégíti a reparativ és a deskriptív igényeket: korábbi megállapításai miatt ugyan vonakodva, de Willis [2015] is kénytelen elismerni - ha a módszer előnyeinél nem is sorolja fel -, hogy a témakódolás egyszerre képes megvalósítani az általa elválasztott két alapvető elemzői megközelítésmódot.

Hátrányok:

- Együtt jár az általánosithatóság hiányával (kérdöiven belül): egy kérdésre kidolgozott kódok (témák) csupán az adott kérdésre nézve tekinthetők érvényesnek, más kérdések esetében érvényüket vesztik. Ez azonban csak akkor tekinthető hiányosságnak, ha univerzálisan alkalmazható kódokat szeretnénk alkotni. Willis megállapításával ellentétben azonban megjegyzendö, hogy egyetemes kódrendszerek alkalmazása (a korábban bemutatottak alapján) sokkal több hátránnyal jár mint előnnyel, így a kódrendszer általánosíthatóságának hiánya mint hátrány csupán látszólagosnak tekinthető.

- Használata kódolási információveszteséget von maga után: más, kódrendszert alkalmazó megoldásokhoz hasonlóan a kódolás, vagyis a témák kidolgozásához szükséges adatredukció elkerülhetetlenül az információs gazdagság redukálásához vezet. Ez a veszély kizárólag a kódolást mellőző, szöveges összefoglalókra épülő elemzési modell esetében alacsonyabb, aminek hátrányait viszont nem egyenlíti ki az alacsonyabb fokú adatredukcióból fakadó előny. Az adatredukcióval párhuzamosan viszont megvalósul a konceptuális tudás bővülése, ami az elemzés egyik (rész)célja.

Willis ([2015] 114. old.) következö, általunk helyenként pontosított/kiegészített táblázata röviden összefoglalja az egyes módszerek legfontosabb jellemzőit. 
A kognitiv interjúk elemzési modelljei

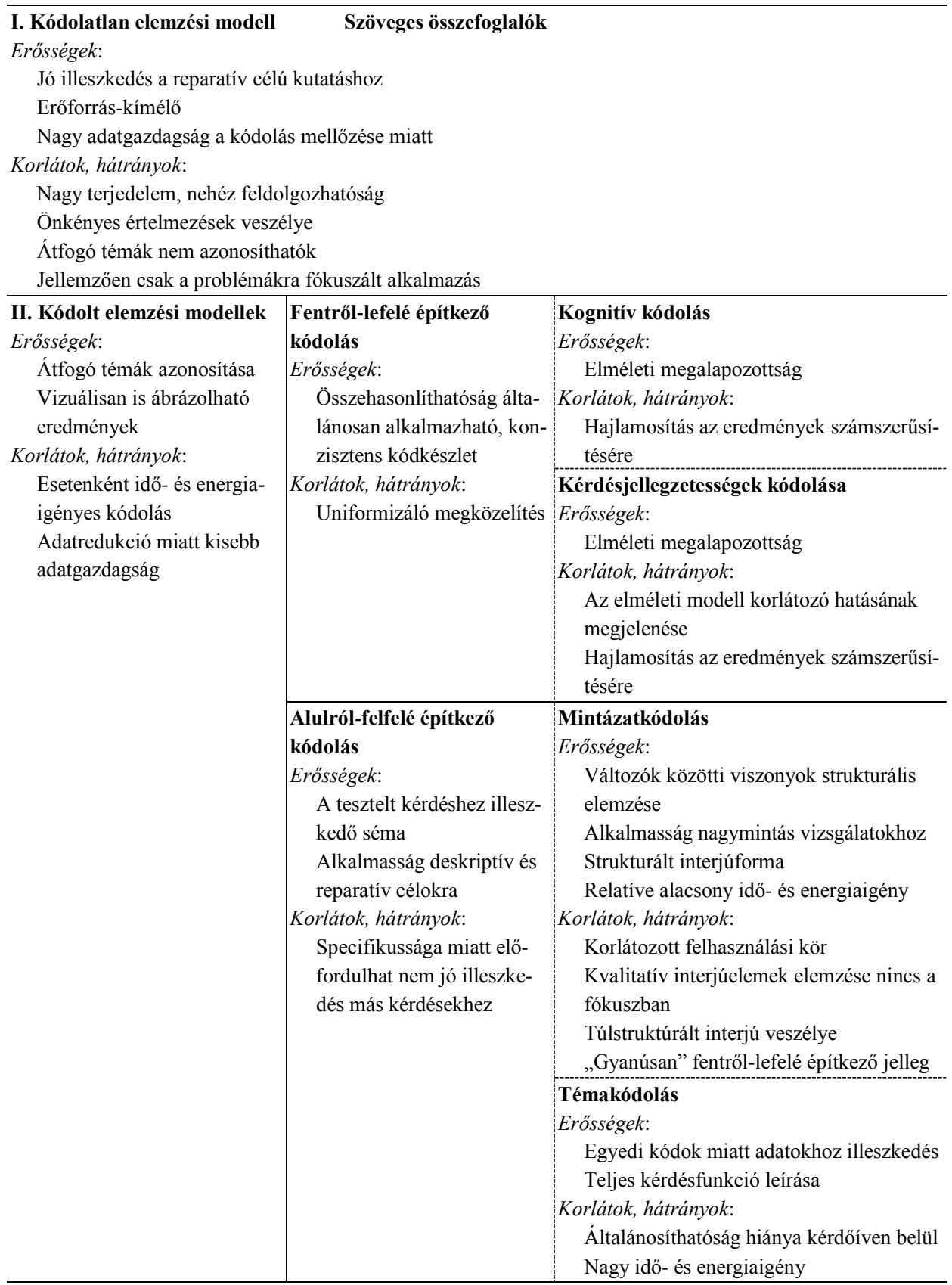

Forrás: Willis ([2015] 114. old.) táblázata alapján. 


\section{Gyakorlati útmutató}

A továbbiakban elsősorban Miller et al. [2014] munkájára alapozva egy gyakorlati útmutatót közlünk a témakódolás modelljéhez Willis [2015] eddigiekben ismertetett általános - és helyenként pontatlan - összefoglalója helyett, illetve, ahol szükséges, azt kiegészítve.

\subsection{Előzetes megfontolások}

Mielőtt a bővebb kifejtésre rátérnénk, Miller et al. [2014] elemzési módszertana kiegészítendő néhány elméleti és gyakorlati megfontolásból eredő szemponttal. Egyrészt a grounded theory alkalmazásához kötődő, kizárólag az interjúszövegekre építő kutatói-elemzői szerep, vagyis a teljes módszertani induktivitás a gyakorlatban megvalósíthatatlan. Ugyan elismerjük, hogy valamilyen (például a Tourangeau-féle) elméleti alapállásból származó kódrendszer ráerőltetése az adatokra súlyos torzító hatásokkal járhat, és kerülendő, de ha csak Polányi $M$. (itt bővebben terjedelmi okokból nem tárgyalandó) ún. hallgatólagos tudáselméletéböl [1958], [1966] indulunk ki, belátható, hogy gyakorlatilag nem lehetséges a teljes objektivitás és a teoretikus pártatlanság. Mint azt Mitev [2012] a szakirodalmat e tekintetben is összefoglaló - bár Polányihoz már nem visszanyúló - tanulmánya is tanúsítja, nem csupán a vizsgálódás eredményére vonatkozó hallgatólagos tudásra érthetjük ezt. Ugyanis minden kutató saját előzetes egyedi tudás-, érték- és készségkomplexumával ${ }^{3}$ kezdi a tesztelési és az elemzési folyamatot, ami akaratlanul is befolyásolja a mintázatok felfedezésében, a tematikus sémák kidolgozásában, összefüggéseik felismerésében és értelmezésében. Az előzetes tudás és tapasztalatok nélküli, tabula rasa jellegü kutatói hozzáállás igényét tehát helyesen tekinti Mitev [2012] hibás mítosznak. A tárgyterülettel kapcsolatos ismeretek nélkül ugyanis még arra is képtelenek volnánk, hogy világos kutatási kérdéseket fogalmazzunk meg, ami lehetetlenné tenne bármilyen tudományos igényü vizsgálódást. ${ }^{4}$

Nem kvantitatív adatelemzésről lévén szó, a mintázatok megfelelő azonosításához a bevezetőben említett művészi-intuitív látásmódra is szükség van. Az azonosított témák (ezekről később még részletesen lesz szó) és a levont következtetések interjúszövegekre való visszavezethetősége azonban ezzel együtt is fontos előnye a

\footnotetext{
${ }^{3}$ Legalább az utóbbi kettőt Weber [1998] mára klasszikussá vált „A tudomány mint hivatás” című, 1917ben tartott előadása is alátámasztja, melyben a szerző a tudományos munka elözetes értékdöntésre való megalapozottságának szerepét, valamint a kutatói ötlet, ihlet fontosságát (is) tárgyalja a tudományos vizsgálódásokkal kapcsolatosan.

${ }^{4}$ Weber [1998] munkája itt ugyancsak releváns lehet, amennyiben már a tudományos munka mint cél is a tudomány keretén belül nem igazolható előfeltevésből születő értékítélet eredménye. Ebből következik, hogy a grounded theory módszertanának használata kutatási eszközként bizonyos értelemben már önmagában is lehetetlenné teszi a kutatói előfeltevés-mentességet.
} 
módszernek. Az egyes lépések, döntések, következtetések aprólékos dokumentálásának egyik fö szerepe éppen az eredmények utólagos racionalizálása, igazolása és validálása. A racionalizálás és a validálás az induktív módszer szokásoshoz képest eleve fordított logikájából adódóan utólag, a kutatói felismerés után történik, amikor a felfedezett témát, összefüggést az interjúszöveghez vagy más, már feltárt témához illesztjük. Polányinak ([1966] 4. old.; kiemelés az eredetiben) az a gyakran idézett megállapítása, hogy „többet tudunk, mint amit el tudunk mondani”, bármilyen aprólékos legyen a dokumentáció, itt is érvényes. A grounded theory alapú elemzésben tehát elkerülhetjük az elözetesen rögzített elméleti keretből fakadó, súlyos torzítás veszélyét, az elemzők személyes meggyőződésének, ismereteinek, készségeinek vagy hiányosságainak stb. hatása azonban nem kiszürhető. Ugyanakkor a teljes folyamat átláthatósága, a kutató személyére, élményeire is kiterjedő reflexivitás, illetve annak megfelelően a kutatócsoport kontrollja olyan keretet jelent, ami által az említett, fontosabb személyes tényezők tudatosíthatók és az elemzés során figyelembe vehetők (Miller et al. [2014]). A már létező koncepciók, elméletek megismerése, vagyis a formális irodalmazás (amit a grounded theory extrém irányzatai egyenesen elvetendőnek tartanak) hovatovább éppen ezt a törekvést segítheti (Mitev [2012]) legalábbis önreflektív kutatói hozzáállás esetén.

Másik megjegyzésünk a szakértói jelenlét kerülésére vonatkozik, amit Miller et al. [2014] is hangsúlyoznak. Az elemzési folyamatban valóban ellenjavalltnak tekinthetjük (az előző bekezdésben foglaltak figyelembevételével) egy előzetesen, elméletileg strukturált szempont szándékolt rávetítését az adatokra, de például a kérdöív revíziójára vonatkozó ajánlások kidolgozásánál már hiba volna nem alkalmazni kérdőívszerkesztési alapismereteinket és megfelelő segédeszközöket (például a korábban említett QAS-modellt). A kérdezés-válaszadás folyamatára és a problémákra vonatkozó teljes kép a szakismeretekkel együtt válik hasznos információvá, ahol a kérdőívszerkesztés általános módszertani keretébe illesztjük be a kognitív teszt elemzése során nyert, az adott kérdések által megragadott jelenségekkel, tesztalanycsoportokkal stb. kapcsolatos többletismereteinket. Willis [2015] három területet jelöl meg, ahol a szakértői megközelítés (szemlélet) „beléphet” az elemzésbe:

- Problémakeresés: szakértőkként tevékenykedünk az interjútervezet elkészítése során éppúgy, mint az interjúzás vagy éppen az elemzés folyamatában. Enélkül képtelenek volnánk az interjút megelőzően tesztkérdéseket alkotni vagy az interjúszituáción belül észlelt problémákra megfelelö, spontán kérdéseket feltenni. A kérdőívszerkesztésről, a kérdezés-válaszadás kognitív pszichológiai és szociológiai jellegzetességeiről való, illetve minden egyes tesztelési munkával gazdagodó egyedi tapasztalatainkból fakadó előzetes tudásunk mindig irányítani fogja tevékenységünket. Minthogy kérdéseink részben eleve 
problémafeltáró célzatúak, az elemzés során figyelnünk kell a felmerülő problémákra. Kognitív kérdőívtesztelésünk annyiban mindenképpen elméletvezérelt lesz, hogy ezekre az ismereteinkre alapozunk a teszt tervezése, kivitelezése és az elemzés során, ami nem csupán megengedhetö, de kulcsfontosságú is a sikeres tesztelésben.

- Problémafeltárás: részben helyt adhatunk Miller et al. [2014] szakértői nézőpontot kizáró megközelítésének, ugyanis empirikus adatokon kell, hogy alapuljon annak kimutatása, hogy milyen problémák azonosíthatók az adott tesztalanycsoporttal felvett interjúk során, és biztosítani kell az elözetes elméleti megközelítés felülírásának vagy kiegészítésének lehetőségét is. Ahol azonban nincs olyan empirikus adat, ami közvetlenül cáfolná a szakértői véleményt, ott megengedhető e vélemény fenntartása, azzal a kitétellel, hogy ennek tényét (tehát azt, hogy az adott értékelés a tesztelés empirikus adatai által nem cáfolt szakértői vélemény) egyértelmủen jelezni kell.

- Problémamegoldás: a kérdés vagy a kérdőív módosításának folyamatát, mint azt korábban kifejtettük, Willis [2015] szerint is a szakértői ismereteknek kell vezérelniük.

\subsection{A témakódolás folyamata}

Az interjúelemzés lényegében egy olyan adatredukciós folyamat, mely során nagy mennyiségü szöveges adatot a vizsgálat célját szolgáló, jelentésteli következtetésekké alakítunk. A szerzők az elemzés öt fő szakaszát különítik el; ezek mindegyike az adatredukció egy-egy lépésének tekinthető:

1. interjúkészítés (narratívák összegyüjtése arról, hogy az interjúalanyok miként válaszolják meg a kérdőív kérdéseit);

2. az interjúszövegek részletes összegzése (az interjúalanyok hogyan értették a kérdést, milyen módon válaszoltak, voltak-e nehézségeik);

3. az összegzések összehasonlítása kérdésenként (voltak-e közös témák az interjúalanyok körében);

4. az azonosított témák interjúalany-típusok szerinti összehasonlítása (eltérnek-e a különböző társadalmi hátterü interjúalanyok tapasztalatai);

5. következtetések levonása (összegzés arról, hogy miként funkcionál egy-egy kérdés a különböző háttérrel rendelkező interjúalanyok körében) (Miller et al. [2014]). 
A nyers adatok tömegét adatredukcióval tematikus sémákká alakítva juthatunk el ahhoz a konceptuális megértéshez, mely révén feltárulnak a tesztalanyok különbözö csoportjainak sajátos kérdésértelmezései, kognitív válaszadási folyamatai és az esetleges válaszadási nehézségeik. Az adatredukció következtében és azzal párhuzamosan zajlik a kutatói tudásanyag bővülése, ahogy az egyre nagyobb konceptuális témák felé haladunk. A két folyamat tehát egymástól nem elválasztható, hanem a kérdezés-válaszadás folyamatának komplex és minél teljesebb megértéséhez vezető szimultán történés.

Az egyedi értelmezésektől elemzői döntések sora vezet a kérdésinterpretációk általános, csoportok közötti viszonyainak, a kérdés teljes funkcionalitásának feltárásáig. Ilyen döntés például nemcsak az, hogy mely információkat minősítünk beépítendőnek az összegzésekbe vagy kihagyandónak azokból, de az interpretációs mintázatok meghatározása is. A visszakövethetőség érdekében így elengedhetetlen minden egyes döntés megfelelő dokumentálása. Minthogy az egyes elemzési lépések egymásra épülnek, az elemzési (adatredukciós) termékek, vagyis az adott lépéseket leíró dokumentumok kritikus fontossággal bírnak az elemzőmunka (át)láthatóvá tételében.

\section{1. lépés: Interjúkészítés}

Szokatlannak tünhet, de az elemzőmunka elemi formájában már az interjúzás során megkezdődik. A kérdező a nyitott, félig strukturált interjú keretében azonosítja a releváns és irreleváns információkat, illetve kérdéseket tesz fel a tesztalanynak az adott témában az ellentmondások és a hiányosságok megszüntetése vagy éppen több információ gyüjtése érdekében. Emellett a témától való elkalandozást „,kordában tartja”, a vizsgálat tárgyára irányítva a tesztalany figyelmét és kommunikációját. Mindehhez az információk azonnali feldolgozására és értékelésére, illetve gyors reagálásra van szükség, ami aktív figyelmet és analitikus gondolkodást igényel. Elemzésre tehát már az interjú folyamán is sor kerül. Fontossága abban rejlik, hogy az interjún belüli azonnali, reaktív elemzés nélkül csekély az esély arra, hogy megfelelően gazdag és részletes, releváns adatokat gyüjtsünk a későbbi, interjúszituáción kívüli elemzési szintek számára. Az interjúkészítő tehát maga is elemző szakértőként vesz részt a folyamatban, és nemritkán tagja a későbbi elemzést végző szakértőgárdának is.

Az interjú mint első elemzési szint terméke az interjúkészítő és a tesztalany interakciójából keletkező nyers adattömeg. Ennek formája lehet: hang- és/vagy videófelvétel, gépelt interjúszöveg, valamint az interjúkészítő jegyzetei. A hangés/vagy videófelvétel megörzése az ellenőrizhetőség és a hitelesség érdekében minden kognitív teszt esetében elengedhetetlen, ezzel szemben az interjúszöveg teljes legépelése nem feltétlenül elvárás. Willis [2015] szerint az utóbbi jellemzően szükségtelen, és (önmagában) gyakran elégtelen is, hiszen a testbeszédet, illetve az egyéb nonverbális jeleket általában nem tartalmazza. D'Ardenne és Collins [2015] a felvételek meghallgatása/megtekintése útján készített összegzést állítják szembe a legépelt 
interjúszövegböl kivonatolt összegzéssel, mindkettőnek azonosítva az előnyeit és a hátrányait is. Az előbbi időhatékonyabb, valamint megfigyelhetővé teszi a szöveges úton nehezen rögzíthető hangszínt, hanglejtést, illetve a szüneteket, az utóbbi viszont az egyes szövegrészek kiemelésével és az ellenőrzés egyszerüsítésével könnyíti meg a munkát. Az összefoglalók hátránya, hogy bennük nehézkesebb hivatkozni a felvétel bizonyos időpontjaira, a gépelt átiratok esetén ezzel szemben könnyebb az oldalés soradatok visszakövethetősége. Willis [2015] a felvételek meghallgatását túlzottan időigényesnek ítéli, és ezért azt a kompromisszumos megoldást javasolja, hogy a kutatók a kérdezői jegyzetek útmutatása alapján a felvételből csak azokat az interjúrészleteket hallgassák/tekintsék meg, melyeknél a jegyzetek pontatlanok, homályosak vagy nem egyértelmủek, illetve a jegyzetek komplex kérdező-tesztalany interakcióról árulkodnak. Az interjúkészítő jegyzetei tehát ugyancsak fontos elemzési alapanyagok. Willis a jegyzetelés folyamatát is elemzőtevékenységnek tekinti, minthogy a jegyzetek maguk is interpretációs folyamat termékei.

\section{2. lépés: Az interjúszövegek részletes összegzése}

Ebben a lépésben a nyers adattömegként megjelenő interjúk szöveges összefoglalóit készítjük el, amelyeknek a kérdőív összes vizsgált kérdésére vonatkozóan a következőket kell tartalmazniuk:

- az interjúalanyok milyen választ adtak az adott kérdésre;

- az interjúalanyok milyen tapasztalatokat vagy észleleteket vettek figyelembe a válaszadás során;

- a válaszadás során felmerülő nehézségek leírását (el kellett-e ismételni az interjúalany számára a kérdést/válaszlehetőségeket, igényelte-e a kérdés/válaszlehetőségek tisztázását);

- az interjúkészítỏ által feltett további kérdésekre adott válaszokat;

- az interjúalany adott kérdéssel vagy válaszlehetőségekkel kapcsolatos zavarát;

- a kérdöív adott kérdésére és az azzal kapcsolatos, további interjúkészítői kérdésekre adott válaszok közötti ellentmondásokat; valamint

- az inkonzisztenciákat az interjúalanyok magyarázataiban arra nézve, hogy miként és miért válaszoltak a kérdésre egy bizonyos módon.

Amennyiben az elemzés során elsősorban a kérdezői jegyzetekre támaszkodunk, és Willis előbb bemutatott javaslatának megfelelően mellözzük az interjúátirat vagy -felvétel teljes vizsgálatát, úgy ezek az elemek azok, amelyeknek a jegyzetekben megfelelő részletességgel meg kell jelenniük. Lényegében ezekkel dokumentáljuk az interjú folyamán zajló elemi analitikus tevékenységet, lehetővé téve a későbbiekben 
az interjú szisztematikus elemzését. Az összefoglalók nem csupán a kérdezésválaszadás megvalósult folyamatának leírását, de ahol indokolt, az interjúidézeteket, az elemzési megállapításokat és a további elemzés lehetséges irányait felvázoló szövegközi megjegyzéseket is tartalmazzák.

Az interjúösszegzések emellett - az egyes interjúk szintjén - lehetővé teszik olyan elemi válaszadási problémák azonosítását is, mint a felidézési nehézségek vagy a félreértelmezések. Ezzel elsősorban a kérdések hibái tárhatók fel, de azokra megoldás is található. A teljes kép megalkotásához és az esetleges tévkövetkeztetések elkerüléséhez azonban az egyedi interjúk tapasztalatainak összegzései nem elegendők. Úgy a reparatív, mint a deskriptív szemszög maradéktalan érvényesítése érdekében további elemzési lépések szükségesek.

\section{3. lépés: Az összegzések összehasonlítása kérdésenként - tematikus séma kidolgozása}

E lépésben a tesztalanyok interjúösszegzések által reprezentált személyes narratívái alapján közös témákat (Willis ezeket nevezi a módszer kódjainak) azonosítunk úgy, hogy interpretációs (értelmezési) mintázatokat keresünk az összegzések adott kérdéshez kapcsolódó szakaszainak áttekintésével. A jelenséget, melyre a kérdés vonatkozik, a tesztalanyok különbözőféleképpen értelmezhetik. Ezek az eltérő jelentéstulajdonítások rajzolják ki az interpretációs mintázatokat. Példaképpen Miller et al. [2014] már két interjú alapján is gyökeresen eltérő értelmezést tapasztaltak egy hallási nehézségeket érintő kérdés esetén: míg az egyik tesztalany a kérdést (a kutatói szándéknak megfelelően) a fizikai hallás esetleges problémáira vonatkoztatta, a másik a hallás egy alternatív jelentésére asszociálva, az elmondottakra való odafigyelés nehézségére. Az interjúösszegzések összehasonlító elemzéséből tehát kiderül, hogy léteznek-e alternatív interpretációs minták. Az így meghatározott témákat (a példában fizikai hallás, illetve odafigyelés) közvetlenül az interjúk alapján határozzuk meg különbségeik kulcsfogalmainak azonosításával. Ezen a ponton kapcsolódik a kognitív interjúelemzési folyamathoz a grounded theory induktív módszere, mely nem elöre kialakított elméleti keretekre alapozva értelmezi a megfigyeléseket, hanem a megfigyelésekből, alulról-felfelé építkezve alakítja ki a teoretikus magyarázatokat.

Mivel ez a témaazonosítási folyamat már az interjúzás, illetve az összefoglalók készitése során spontán is megkezdődhet, a három elemzési lépés gyakran - bizonyos mértékben - szimultán zajlik. Az interjúzás és az elemzés ismétlődő, (részben) párhuzamos folyamatában a Glaser és Strauss [1967] által állandó összehasonlításnak nevezett elv alapján folyamatosan „elöre-hátramozgunk” a nyers szöveges adatok, a témák és a formálódó elméleti megállapítások között.

Az összehasonlítások alapján gyakran felismerhetők az interpretációs mintázatok különböző variációi is (például az, hogy a hallási nehézségekre vonatkozó kérdést 
zajos vagy csendes környezetre vonatkoztatva értelmezik-e a tesztalanyok). A válaszok tehát még azonosan értelmezett hallásfogalom (fizikai hallás) esetén is szignifikánsan különböző értelmezésmódokon alapulhatnak. A komplexitást kezelendő, Miller et al. [2014] az egyes kérdőívkérdésekhez tartozó értelmezési mintázatokat és variációkat fastruktúrában megjelenített tematikus séma alkalmazásával javasolják átláthatóvá tenni. Ennek eredményeként akár horizontálisan többelemü és vertikálisan többszintű ábrát is kaphatunk. Egy adott kérdés esetében pedig jellemzően több különböző téma ismerhető fel az összehasonlítások során, melyek a kérdés kulcselemeit reprezentálják. Ezek mindegyikének ábrázolásával láthatóvá válnak a kérdezés-válaszadás folyamatának interpretív dimenziói, mindazok a jellegzetességek, amelyek a konkrét kérdésre adandó választ a tesztalanyok esetében valósan befolyásolják (szemben egy elözetesen felállított elméleti modell szerinti értelmezéssel). A kérdéshez kapcsolódó tematikus séma vizsgálata tehát közvetlen betekintést enged a kérdés által megragadott jelenség természetébe. (Lásd a következő elemzési lépést is bemutató ábrát.)

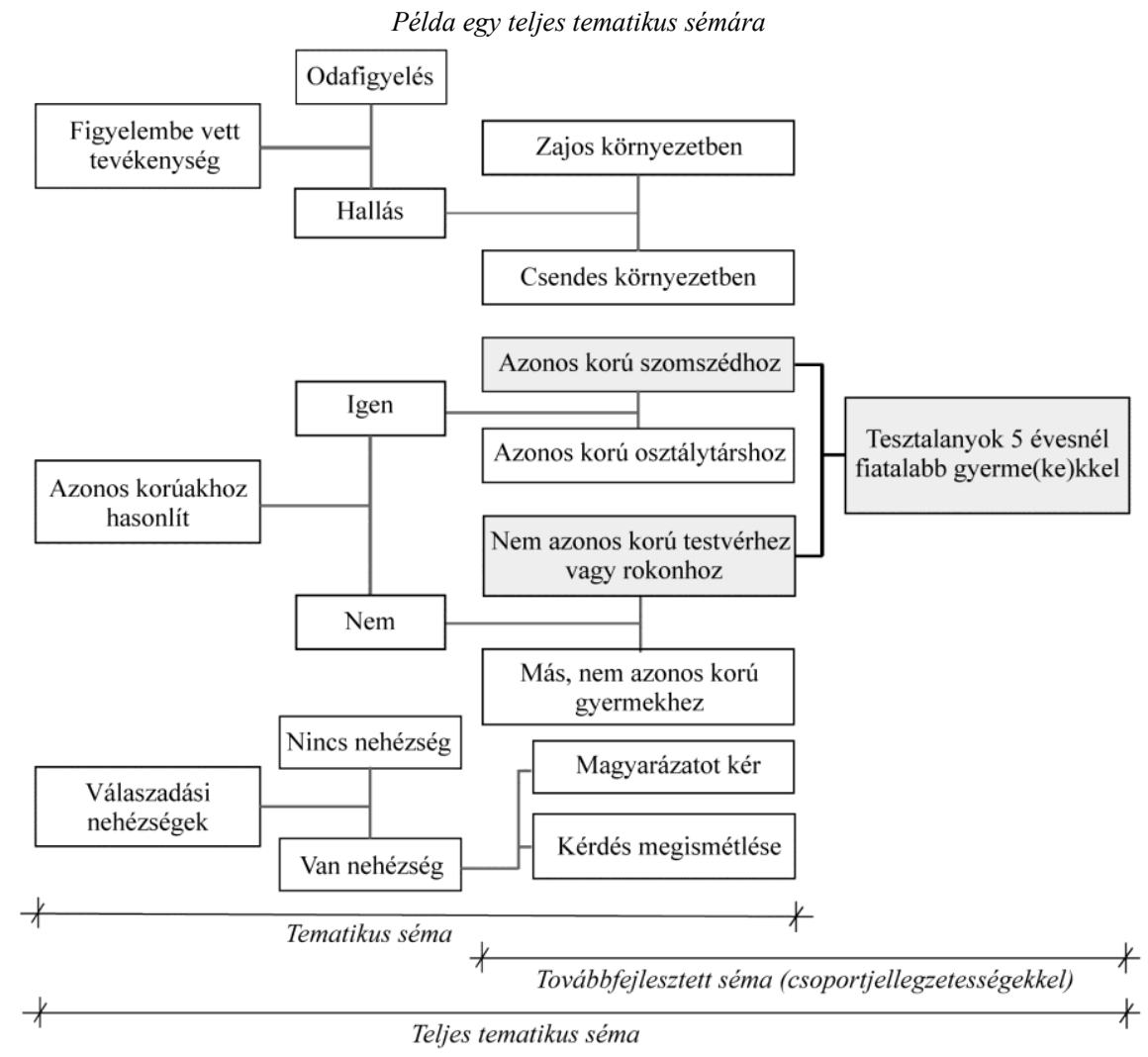

Forrás: Saját összeállítás Miller et al. [2014] alapján. 
A tematikus sémák elemzési szintjén elvégzett munka terméke tehát a(z akár többdimenziós) tematikus séma, melynek minden ága az egyedi interjúkból ered és azokra visszavezethető. A témák megjelenésének magyarázata és a mintázatok közötti viszonyok nem mindig nyilvánvalók - teljes megértéshez jellemzően csak a következő elemzési szint juttat, ahol a mintázatok tesztalanycsoportok közötti összehasonlítása történik. Enélkül nem lehetséges kellő biztonsággal megállapítani, mi okozhat egy kérdés esetében problémát, és hogyan lehetséges annak kiküszöbölése.

\section{4. lépés: Az azonosított témák interjúalany-típusok szerinti összehasonlítása - továbbfejlesztett séma kidolgozása}

Az elemzés negyedik szintjén a tesztalanyok csoportjai között végzünk szisztematikus összehasonlítást annak kiderítése érdekében, vajon egyes témák jellemzőbbek-e bizonyos csoportokra nézve. A csoportközi összehasonlítás teszi lehetővé a válaszadást befolyásoló, a sajátos társadalmi helyzetből fakadó hatások felfedését éppúgy, mint annak a megértését és a magyarázatát, hogy a tesztalanyok miként és miért az adott módon értelmezik, illetve dolgozzák fel a kérdőív kérdéseit. A témák csoportközi összehasonlításával egy továbbfejlesztett sémát állítunk elő.

Az interjúalanyok csoportjait meghatározhatja/meghatározhatják:

- a kérdések tartalma (például egy dohányzásra vonatkozó kérdést máshogy értelmezhetnek a nemdohányzók, az alkalmi, illetve a rendszeres dohányzók csoportjai);

- demográfiai jellemzők (az értelmezésre és a válaszadásra például a nemhez, az iskolai végzettséghez, a jövedelemhez, az életkorhoz, az etnikumhoz stb. köthető tapasztalatok is hatással lehetnek);

- nyelvi különbségek (ha az interjúk több különböző nyelven készülnek);

- lakóhely (amennyiben az interjúk több helyszínen zajlanak, a regionális különbségek is befolyásolhatják a kérdések értelmezését és a válaszadás folyamatát).

\section{5. lépés: Következtetések levonása}

Az elemzés utolsó lépésében a kidolgozott sémák alapján összegezzük a vizsgált kérdések, illetve a kérdőív egészének ,teljesítményét”. A korábbi lépésekben hozott következtetések szintézisével és az azokból levonható további következtetések révén leírhatjuk az egyes kérdések müködését. A leírás a következőket kell, hogy tartalmazza:

- a kérdések különböző értelmezési módjai;

- a tesztalanyok válaszalkotásának módjai; 
- a tesztalanyok által érzékelt nehézségek - ideális esetben magyarázattal;

- a tesztalanycsoportok különböző kérdésfeldolgozása - ideális esetben magyarázattal.

Miller et al. [2014] véleménye szerint a végkövetkeztetések kidolgozásánál is figyelnie kell az elemzőnek arra, hogy a leírt eredmények kizárólag empirikus adatokon nyugodjanak, mivel a grounded theory módszerének szellemisége szerint a „szakértői vélemény” vagy éppen az önkényes elemzői értelmezések kerülendők. Ez azonban, mint már bemutattuk, nem valósítható meg teljes mértékben - az előzetes elméleti és tapasztalati, illetve a Polányi-féle [1958], [1966] hallgatólagos tudás ugyanis mindig irányítja és egyedivé teszi a teljes tesztfolyamatot, így benne az interjúfelvételt és -elemzést, illetve a következtetések kidolgozását. A valóságban tehát legfeljebb az előzetes kutatói tudástól eltérő tartalmú interpretációs sémákra való nyitottság, azaz egyfajta kutatói elóitélet-mentesség és az adatokra való visszavezethetőség várható el, melyet a Chepp és Scanlon [2014] által javasolt kutatói önreflexió egészíthet ki. Ez utóbbi annak dokumentálását jelenti, hogy a kutató személye milyen módon befolyásolta a tesztfolyamatot és annak eredményét akár az adatgyüjtés során, akár az értelmezés módjában. A teljes tesztfolyamat átláthatósága és a kutatói közösség kontrollja is hozzájárul az elemzés érvényességéhez.

Mindent összevetve, a leginkább ajánlható elemzési módszer a Willis [2015] által témakódolásnak nevezett, grounded theory alapú interpretív kognitív interjúelemzési modell. Az ily módon felépülő elemzőmunka végterméke (konklúziója) képes megfelelni a Willis [2015] által meghatározott reparatív és deskriptív igényeknek is: meg tudja ragadni úgy a kérdésekkel kapcsolatos problémákat, mint az azok funkcionalitásának viszonylag teljes spektrumát. Bár e modell nagyságrendekkel nagyobb energiabefektetést igényel az elemzői gárda részéről, mint a többi - ehhez képest csupán részleges elemzést biztosító - modell, e többletmunka megtérül. Az egyéb modellek gyakran torz képet közvetítenek, és így hibás következtetésekhez vezethetnek, szemben a témakódolás modelljével. Az egyes elemzési szinteken ugyanis rendkívül eltérö következtetéseket is alkothatunk. A kérdések értelmezésének és a válaszadás folyamatának hátterében meghúzódó interpretációs sémák teljes feltárása nélkül eredményeink legjobb esetben csak részlegesek, legrosszabb esetben pedig akár félrevezetők is lehetnek (Miller et al. [2014]). A kognitív kérdőívtesztelés révén a kérdések fejlesztésére tett erőfeszítéseink tehát a legnagyobb jóindulattal is bizonytalanok, illetve megkérdőjelezhetők olyan, minden lépésében az előző lépés(ek)re épülö, teljes elemzés nélkül, mely az interjúkban elhangzottakra vagy történtekre visszavezethető következtetéseket eredményez. 


\subsection{A kérdőív fejlesztését célzó ajánlások kidolgozása a témakódolásra építve}

A kognitív tesztelés folyamatában a Miller et al. [2014] által kidolgozott, témakódolásra épülő elemzés módszertanát a kérdőívre vonatkozó ajánlások megfogalmazása követi.

E lépésben, amennyiben az elemzés eredményeképpen több alternatív módosítási lehetőség is kirajzolódik, részletesen dokumentált és indoklással ellátott revíziós javaslato(ka)t adunk a levont következtetések alapján a vizsgált kérdések mindegyikére. Ekkor (a korábban leírtaknak megfelelően) az interjúelemzés során feltárt problémák megoldásához az elemző kérdőívszerkesztési ismereteire és az elemzés során feltárt rendezőelvek, összefüggések ismeretére (a kidolgozott konceptuális megértésre) egyaránt szükség van, azok együttesen alkalmazandók. Mivel az adott tesztalanycsoport(ok)ra nézve nem csupán a kérdésekkel kapcsolatos problémák, de (ideális esetben) a kérdések teljes müködését, valamint a problémák és működésmódok okait is feltártuk, az ajánlásokat ezeket szem előtt tartva kell kidolgoznunk. Tehát nem csupán a felmerült problémák elhárítására kell koncentrálnunk, hanem arra is, hogy a javaslatok alapján megváltoztatott vagy újonnan kidolgozott kérdésformák, válaszehetőségek stb. azokhoz az interpretációs sémákhoz is illeszkedjenek, amelyek tesztalanyaink sajátos értelmezési és válaszadási folyamatát jellemzik a kérdések és a válaszok által megragadni, vizsgálni kívánt jelenségekkel kapcsolatosan. Az egyes interpretációs mintázatok, témák és csoportok közötti összefüggések, interpretációs csoportjellegzetességek stb. jelentik azt a mozgásteret, amiben a kérdőívszerkesztési tudásunk felhasználásával igyekszünk leküzdeni a kérdések értelmezésében vagy a válaszadás folyamatában megjelenő, egyéni/csoportspecifikus problémákat. Ebben a mozgástérben ugyancsak nem elhanyagolható a kutatói kreativitás jelentősége. Az elemzés alapján levont következtetések, az általános kérdőívszerkesztési elvárások és a kérdések által megragadni, mérni kívánt jelenségek (vagyis az eredeti kutatói szándék) hármasának koherenciája a lehető legnagyobb mértékben kell, hogy érvényre jusson a tesztfolyamat végtermékeként is értelmezhető revíziós ajánlásokban. Az ezek alapján összeállított kérdőívkérdések és a kérdőív egésze egyszerre „simul bele” a feltárt interpretációs mintázatokba, teljesíti (például a QAS-protokollal irányított és ellenőrzött módon) az alapvető kérdőívszerkesztési elvárásokat, és felel meg a kérdőív lényegi céljának, a gyüjteni kívánt adatokra vonatkozó kutatói igényeknek. E ponton sem szabad elfelejtenünk: a csoportspecifikus vagy a gyakran megjelenő problémák kezelése nem élvezhet előnyt a ritka vagy egyszeri problémákéval szemben. Az előbbi annyiban jelent könnyebb feladatot, hogy ahhoz több „fogódzóval” rendelkezünk.

Minden döntést és ajánlást megfelelően dokumentálni kell, hogy később igazolhatók és az interjúszövegekre visszakövethetök legyenek. Amennyiben valamilyen 
problémára adott (az előző bekezdésben kifejtett három elem által meghatározott) kereten belül nem találunk megfelelő megoldást, - ha lehetséges - rögzítenünk kell egy vagy több „legkevésbé rossz” verziót is korlátaikkal és torzítási veszélyeikkel együtt (a pontos és alapos dokumentáció ilyen esetben is alapvető elvárás).

A következőkre tehetök változtatási javaslatok (D'Ardenne-Collins-Blake [2015]):

\section{Megfogalmazás}

- a nehezen érthetö/félreérthetö/többértelmü/bizonytalanul értelmezhető szavak, kifejezések (például szakkifejezések) módosítása;

- a mondatszerkezet megváltoztatása vagy a kérdés teljes újrafogalmazása nem megfelelő kérdésstruktúra okozta félreértés esetén;

- a kérdéshossz lerövidítése, ha az okozta a problémás értelmezést (például a kérdés szükségtelen magyarázatot tartalmaz).

2. Válaszlehetőségek: előfordulhat, hogy a teszt eredményei alapján a válaszlehetőségek vagy a válaszadás módja nem illeszkedik megfelelően a kérdéshez, ami megnehezíti vagy ellehetetleníti a válaszadást. Ez esetben nem a kérdés, hanem a válaszlehetőségek módosítandók átfogalmazással, további válaszlehetőségek megadásával, a skálafelbontás megváltoztatásával, a tesztalanyok által egymást átfedőként észlelt válaszlehetőségek módosításával, esetleg összevonásával stb.

3. Kérdés törlése: amennyiben a tesztalanyok képtelenek megfelelő választ adni a kérdésre, lehetséges, hogy irreális elvárás begyüjteni az adott válaszadói csoporttól a mérendő jelenségre, jellemzőre vonatkozó adatokat. Egyéb megoldás hiányában a kérdés teljes törlésére mint „legkevésbé rossz" megoldásra is sor kerülhet.

4. Szerkezet, tagolás: jellemzően önkitöltős kérdőíveknél lehet szükség a szerkezet/tagolás módosítására, amennyiben úgy találtuk, hogy a tesztalanyok nem tudták megfelelően követni az ugratásokat, vagy következetesen figyelmen kívül hagytak bizonyos válaszlehetöségeket, instrukciókat, valamint (például táblázatba foglalt kérdések esetén) nehézségeket jeleztek stb.

5. Alternatív adatgyüjtési mód alkalmazása: ha a tesztalanyok képtelenek vagy nem hajlandók megfelelő információkat adni, radikális változtatások is végrehajthatók. Lehetséges, hogy meg kell fontolnunk az adatgyüjtés módszerének és/vagy forrásának megváltoztatását (például napló alkalmazása kérdőív helyett, [amennyiben módunkban áll] adminisztratív adatforrások használata stb.).

6. További tesztelés: ha bármilyen okból nincs elegendő információnk javaslatok megfogalmazására, további (nem feltétlenül csak kognitív!) tesztelésre lehet szükség. 
Amennyiben úgy találtuk, hogy a kérdés problémamentes, és értelmezésiválaszadási mintázatai teljes egészében megfelelnek az eredeti szándéknak, nincs szükség változtatásra. Ezt az adott kérdés tárgyalásánál ugyancsak jelezni kell megfelelö indoklás mellett.

A kognitív tesztfolyamatot záró jelentés formai és egyéb követelményeit jelen tanulmányban nem kívánjuk bővebben tárgyalni. A nemzetközi szakirodalom több lehetséges formátumot kínál, így például Boejie és Willis [2013] általánosan használható, CIRF (cognitive interviewing reporting framework - keretrendszer kognitív interjús jelentésekhez) elnevezésü, tízelemes jelentésstruktúráját vagy Chepp és Scanlon [2014] interpretív módszertanra optimalizált kognitív tesztriportját.

\section{4. Összefoglalás}

A kognitív tesztfolyamat egyik legfontosabb állomása a kognitív interjúk elemzése. Tanulmányunkban arra tettünk kísérletet, hogy áttekintsük és röviden összefoglaljuk a kognitív interjúk elemzésére és az az alapján kidolgozott ajánlásokra vonatkozó legfontosabb módszertani ismereteket. Számba véve a különböző megközelítések előnyeit és hátrányait, a jelenleg ismert legmegfelelőbb elemzési módszernek a Miller et al. [2014] által kidolgozott, grounded theory alapú, integratív (egyaránt deskriptív és reparatív) témakódolási modellt tekinthetjük. Ez részletesen kidolgozott elemzési eljárást nyújt a kérdezés-válaszadás során lejátszódó kognitív folyamatok feltérképezéséhez és interpretív keretben történő értelmezéséhez.

A modell gyakorlati alkalmazásakor az adatredukció folyamatának fő lépéseit a kérdések megválaszolásának mikéntjére vonatkozó narratívák összegyüjtése, az interjúszövegek összegzése, a közös témák kérdésenkénti feltárása, az azonosított témák interjúalany-típusok szerinti összevetése, végül pedig annak a kérdésnek a megválaszolása követi, hogy miként funkcionál egy-egy kérdés a különböző társadalmi hátterủ interjúalanyok körében. A témakódolás során tehát az interjúalanyok kognitív válaszadási folyamatai, a különböző társadalmi csoportok tagjainak sajátos kérdésértelmezései és válaszadás során tapasztalható nehézségei az ún. tematikus sémák azonosításának folyamatában tárulnak fel.

A modell megfelelő végrehajtásával egy átlátható, hiteles és érvényes elemzést követően megalapozott kérdőív-optimalizálási javaslatok megfogalmazására nyílik lehetöségünk. 


\section{Irodalom}

BeAtTy, P. C. - Willis, G. B. [2007]: Research synthesis: the practice of cognitive interviewing. Public Opinion Quarterly. Vol. 71. No. 2. pp. 287-311. https://doi.org/10.1093/poq/nfm006

BoeJIE, H. - WiLLIS, G. [2013]: The Cognitive Interviewing Reporting Framework (CIRF) towards the harmonization of cognitive testing reports. Methodology: European Journal of Research Methods for the Behavioral and Social Sciences. Vol. 9. No. 3. pp. 87-95. https://doi.org/10.1027/1614-2241/a000075

BREKHUS, W. [2007]: The Rutgers School: a Zerubavelian culturalist cognitive sociology. European Journal of Social Theory. Vol. 10. No. 3. pp. 448-464. https://doi.org/10.1177/ 1368431007080705

Charmaz, K. [2006]: Constructing Grounded Theory: A Practical Guide Through Qualitative Analysis. SAGE. Thousand Oaks.

Chepp, V. - GRAY, C. [2014]: Foundations and new directions. In: Miller, K. - Willson, S. - Chepp, V. - Padilla, J.-L. (eds.): Cognitive Interviewing Methodology. John Wiley \& Sons. Hoboken. pp. 7-14. https://doi.org/10.1002/9781118838860.ch2

ChePP, V. - ScAnlon, P. [2014]: Conveying results. In: Miller, K. - Willson, S. - Chepp, V. Padilla, J.-L. (eds.): Cognitive Interviewing Methodology. John Wiley \& Sons. Hoboken. pp. 69-84. https://doi.org/10.1002/9781118838860.ch6

Collins, D. (ed.) [2015a]: Cognitive Interviewing Practice. SAGE. London. http://dx.doi.org/ $10.4135 / 9781473910102$

Collins, D. [2015b]: Analysis and interpretation. In: Collins, D. (ed.): Cognitive Interviewing Practice. SAGE. London. pp. 162-174. http://dx.doi.org/10.4135/9781473910102

Collins, D. - Gray, M. [2015]: Sampling and recruitment. In: Collins, D. (ed.): Cognitive Interviewing Practice. SAGE. London. pp. 80-100. http://dx.doi.org/10.4135/9781473910102

D'Ardenne, J. - Collins, D. [2015]: Data management. In: Collins, D. (ed.): Cognitive Interviewing Practice. SAGE. London. pp. 142-161. http://dx.doi.org/10.4135/9781473910102

D'Ardenne, J. - Collins, D. - Blake, M. [2015]: Application of findings. In: Collins, D. (ed.): Cognitive Interviewing Practice. SAGE. London. pp. 175-194. http://dx.doi.org/10.4135/ 9781473910102

FÖLDVÁRI M. - MúJDRICZA F. [2018]: A kognitív kérdőívtesztelés módszertana: a kognitív interjúfelvétel. Statisztikai Szemle. 96. évf. 5. sz. 449-467. old. https://doi.org/10.20311/stat 2018.05.hu0449

Glaser, B. G. - StRauss, A. L. [1967]: The Discovery of Grounded Theory: Strategies for Qualitative Research. Aldine Transaction. Somerset. http://dx.doi.org/10.1097/00006199196807000-00014

Jabine, T. - Straf, M. - TAnuR, J. - Tourangeau, R. (eds.) [1984]: Cognitive Aspects of Survey Methodology: Building a Bridge Between Disciplines. National Academy Press. Washington, D.C. https://doi.org/10.17226/930

LEE, J. [2014]: Conducting cognitive interviews in cross-national settings. Assessment. Vol. 21. No. 2. pp. 227-240. https://doi.org/10.1177/1073191112436671

MiLler, K. [2011]: Cognitive interviewing. In: Madans, J. - Miller, K. - Maitland, A. - Willis, G. (eds.): Question Evaluation Methods: Contributing to the Science of Data Quality. John Wiley \& Sons. Hoboken. pp. 51-75. https://doi.org/10.1002/9781118037003 
Miller, K. - Mont, D. - Maitland, A. - Altman, B. - Madans, J. [2010]: Results of a crossnational structured cognitive interviewing protocol to test measures of disability. Quality and Quantity. Vol. 45. No. 4. pp. 801-815. https://doi.org/10.1007/s11135-010-9370-4

Miller, K. - Willson, S. - ChePP, V. - RyAn, J. M. [2014]: Analysis. In: Miller, K. - Willson, S. Chepp, V. - Padilla, J. L. (eds.): Cognitive Interviewing Methodology. John Wiley \& Sons. Hoboken. pp. 35-50. https://doi.org/10.1002/9781118838860.ch4

Mitev A. Z. [2012]: Grounded theory, a kvalitatív kutatás klasszikus mérföldköve. Vezetéstudomány. 43. évf. 1. sz. 17-30. old.

PolÁNYI, M. [1958]: Personal Knowledge. Routledge. London.

PolÁnyi, M. [1966]: The Tacit Dimension. Routledge \& Kegan Paul. London.

TourangeAu, R. [1984]: Cognitive science and survey methods: a cognitive perspective. In: Jabine, T. - Straf, M. - Tanur, J. - Tourangeau, R. (eds): Cognitive Aspects of Survey Design: Building a Bridge Between the Disciplines. National Academic Press. Washington, D.C. pp. 73-100. https://doi.org/10.17226/930

WeBER, M. [1998]: A tudomány mint hivatás. In: Weber, M. (szerk.): Tanulmányok. Osiris Kiadó. Budapest. 127-155. old.

Willis, G. B. [1994]: Cognitive Interviewing and Questionnaire Design: A Training Manual. Cognitive Methods Staff Working Paper Series. No. 7. National Center for Health Statistics. Hyattsville.

WILLIS, G. B. [2015]: Analysis of the Cognitive Interview in Questionnaire Design. Oxford University Press. Oxford.

WiLlsOn, G. B. - LesSLER, J. T. [1999]: The BRFSS-QAS: A Guide for Systematically Evaluating Survey Question Wording. Research Triangle Institute. Durham.

Willson, S. - Miller, K. [2014]: Data collection. In: Miller, K. - Willson, S. - Chepp, V. - Padilla, J.-L. (eds.): Cognitive Interviewing Methodology. John Wiley \& Sons. Hoboken. pp. 1534. . https://doi.org/10.1002/9781118838860.ch3

\section{Summary}

The analysis of the interviews and, based on the results of the analysis, elaboration of the revisions to develop the tested questionnaire is of major importance in every questionnaire pre-test using cognitive interviewing methods. Until recently, the special methodology of the analysis of cognitive interviews was a rather neglected field not only in Hungary but also internationally. The authors present the most important relevant methods in line with the latest international literature addressed to fill this hiatus. Analysis aiming for a complete functional understanding of the question-response process has to meet the demands of the descriptive as well as the reparative approach at the same time. At present, the inductive interview analysis method based on grounded theory elaborated by the interpretive school can provide us with the best framework for such analytic purposes. Therefore, after presenting the alternative methodologies, the authors explain this analysis method called theme coding in depth, noting the limitations stemming from its inductive character and demonstrating the details of designing suggestions for questionnaire revision that can be regarded as the ultimate goal of the entire cognitive testing process. 